\title{
Alpha-Glucosidase Inhibitory Activity of Garcinia lateriflora Blume Leaves
}

\author{
Putu Gita Maya Widyaswari Mahayasih ${ }^{1 *}$, Berna Elya ${ }^{1 *}$, Muhammad Hanafi $^{2}$ \\ ${ }^{1}$ Faculty of Pharmacy, Universitas Indonesia, Depok 16424, Indonesia. \\ ${ }^{2}$ Research Center for Chemistry, Indonesian Institute of Science, Serpong,Tangerang 15310 Indonesia.
}

\begin{tabular}{|c|c|}
\hline ARTICLE INFO & ABSTRACT \\
\hline $\begin{array}{l}\text { Article history: } \\
\text { Received on: } 26 / 02 / 2017 \\
\text { Accepted on: } 22 / 06 / 2017 \\
\text { Available online: } 30 / 10 / 2017\end{array}$ & $\begin{array}{l}\text { Garcinia lateriflora Blume., that belongs to the genus Garcinia, is known to contain polyphenol compounds that } \\
\text { are likely to inhibit alpha-glucosidase in the treatment of diabetes mellitus. Therefore, this study aimed to } \\
\text { evaluate and acquire the most biologically active fraction from leaves of G. lateriflora in inhibiting alpha- } \\
\text { glucosidase. The separation of the active fraction was conducted using column chromatography and identified }\end{array}$ \\
\hline $\begin{array}{l}\text { Key words: } \\
\text { alpha-glucosidase, column } \\
\text { chromatography, Diabetes } \\
\text { mellitus, Garcinia } \\
\text { lateriflora,leaves, in vitro } \\
\text { assay. }\end{array}$ & $\begin{array}{l}\text { spectrophotometric method with p-nitrophenyl- } \alpha \text {-D-glucopiranoside as the substrate. } 17 \text { and } 12 \text { fractions were } \\
\text { obtained from ethyl acetate and methanol extracts, respectively. Fraction } 13 \text { (EA13) of ethyl acetate extract and } \\
\text { fraction } 10(\mathrm{Me} 10) \text { of methanol extract were showed the highest percent inhibition compared with the other } \\
\text { fraction with } \mathrm{IC}_{50} \text { values } 8.96 \mu \mathrm{g} / \mathrm{ml} \text { and } 18.52 \mu \mathrm{g} / \mathrm{ml} \text {, respectively. While the } \mathrm{IC}_{50} \text { value for Acarbose is } 39.53 \\
\mu \mathrm{g} / \mathrm{ml} \text {. Furthermore, fraction EA13 is the most active fraction in inhibiting alpha-glucosidase compared with the } \\
\text { extract, other fractions, and Acarbose. }\end{array}$ \\
\hline
\end{tabular}

\section{INTRODUCTION}

Diabetes mellitus (DM), as one of metabolic disorder, has become a serious concern in the recent decade. It is associated with a range serious complication that can result in reduced quality of life and premature mortality (WHO, 2016). The prevalence of Diabetes Mellitus was reported to increase from year to year. In 2015 approximately $8.8 \%$ of the world population or around 415 million people around the world were reportedly suffering from diabetes. This number is expected to increase to approximately $10.4 \%$ in 2040 . In 2015 , it was reported that the DM has been the cause of death for 5 million

\footnotetext{
* Corresponding Author

Putu Gita Maya Widyaswari Mahayasih \& Berna Elya, Faculty of Pharmacy, Universitas Indonesia, Kampus UI Depok, Depok 16424, Indonesia. Phone: +6285737513123; +6281314161497

Email: aya.mahayasih@gmail.com;berna.elya@gmail.com
}

people worldwide. The country with the highest population of diabetics are in China, India, USA, Brazil, Mexico, and Indonesia (IDF, 2015). Diabetes mellitus can be characterized by postprandial hyperglycemia, which then can stimulate insulin secretion. Postprandial hyperglycemia can lead to the development of type 2 diabetes and its complications, such as cardiovascular diseases (He et al., 2015). One of the therapeutic approaches that can be used to reduce postprandial hyperglycemia is by inhibiting the enzyme which hydrolysis carbohydrates, particularly alphaglucosidase enzymes in the digestive tract and prevent the absorption of glucose (Derosa and Maffioli, 2012). Inhibition of alpha-glucosidase enzyme can effectively reduce the digestion of complex carbohydrates and its absorption, so that postprandial glucose levels in pre-diabetic patients can be reduced and help to prevent the development of type 2 DM (He et al., 2012). Therefore, the mechanism of alpha-glucosidase inhibitor can be one of the potential approaches to find a new agent of drug in the treatment of diabetes mellitus, particularly type $2 \mathrm{DM}$. 
Plant have long been becoming one of the potential sources of drugs, particularly to treat diabetes mellitus by inhibiting alpha-glucosidase enzyme (Elya et al., 2012a; Mun'im et al., 2013; Yin et al., 2014). Garcinia lateriflora Blume., which belongs to genus Garcinia and family Clusiaceae, is one of the native plants found in Indonesia and mainly used as a folk medicine and foodstuffs by Indonesian native people (Satyanti and Cahyaningsih, 2013).

It has been reported that phenolic compound, such as xanthone and flavonoid, from the extract of G. lateriflora stem bark display proteasome-inhibitory activity and, has cytotoxic activity against HT-29 human colon cancer (Ren et al., 2010) and P388 cancer cell line (Kosela et al., 1999). Another study proved that methanol leaves extract of G. lateriflora showed high antioxidant scavenging activity of 1,1-diphenyl-2-picrylhydrazyl (Elya et al., 2012c). There are many kinds of research that have been investigated in the inhibitory activities of species from genus Garcinia, but none on Garcinia lateriflora Blume. Xanthone from G. mangostana (Ryu et al., 2011) and depsidone from $G$. brevipedicellata (Ngoupayo et al., 2008) had shown alphaglucosidase inhibitory activity. Leaves extract of G. bancana Miq, G. daedalanthera Pierre, G. kydia Roxb, G. hombroniana, and G. rigida, which were collected from Indonesia, showed moderate to high inhibitory activity of alpha-glucosidase with $\mathrm{IC}_{50}$ values 2.33 $-24.48 \mu \mathrm{g} / \mathrm{ml}$ (Elya et al., 2012).

Based on chemotaxonomic approach, leaves extract of $G$. lateriflora Blume could be expected to have activity on inhibiting alpha-glucosidase and could be used as one of choices therapy for treatment of diabetes mellitus and prevent the development of its complication.

\section{MATERIAL AND METHODS}

\section{Plant materials}

The leaves of Garcinia lateriflora Blume were collected from the Bogor Botanical Garden, Indonesia. It was identified by The Center for Plant Conservation from Bogor Botanical Garden.

\section{Extraction and Fractionation}

Simplisia powder $(5 \mathrm{~kg})$ of dried leaves was macerated, successively, with three different distilled solvent, $n$-hexane, ethyl acetate, and methanol, for $24 \mathrm{~h}$ at $25^{\circ} \mathrm{C}$. Each extraction was performed three times. Extracts were evaporated by a rotary evaporator to yield n-hexane, ethyl acetate, and methanol crude extracts (Zahratunnisa et al., 2017).

Each extract was then tested for the inhibition of alphaglucosidase. Extract with highest alpha-glucosidase inhibitory activity was further separated. As much as $20 \mathrm{~g}$ of ethyl acetate and methanol extracts was fractionated based on previous method (Elya et al., 2012c) over column chromatography $(4.5 \times 40 \mathrm{~cm})$ with stationary phase silica gel 60 and eluted with a step gradient polarity solvent of n-Hexane - Ethyl acetate - Methanol as mobile phase to give 239 and 228 initial fractions. The fraction which had same TLC profile was collected into one fraction to obtain a number of fractions from the extracts. The collected fraction was then tested for the alpha-glucosidase inhibitory activity.

\section{Determination and Identification of Chromatography Profile}

Chromatography profile was conducted using TLC silica gel $60 \mathrm{~F}_{254}$ plates (Merck, Germany) and determined their profile with UV lamp at 254 and $366 \mathrm{~nm}$ (Ahmad et al., 2017). The spot was identified by $\mathrm{AlCl}_{3}$ and $10 \% \mathrm{H}_{2} \mathrm{SO}_{4}$ spray reagent (Ahmad et al., 2016; Yagi et al., 2012).

\section{Inhibition of Alpha-Glucosidase Assay}

Inhibition of alpha-glucosidase assay was done by following a previously published method with slight modification (Zahratunnisa et al., 2017). $30 \mu \mathrm{l}$ samples with various concentrations ( 5 to $500 \mu \mathrm{g} / \mathrm{ml}$ ) were put in 96 microplate wells with $36 \mu$ of phosphate buffer $\mathrm{pH} 6.8$ and $17 \mu 1$ of $4 \mathrm{mM}$ substrate p-nitrofenil- $\alpha$-D-glucopiranoside (p-NPG) (Sigma-Aldrich, Switzerland).

The mixture then incubated for 5 minutes at $37^{\circ} \mathrm{C} .17 \mu \mathrm{l}$ of $\alpha$-glucosidase (Saccharomyces cerevisiae, Sigma-AldrichGermany) at concentration 0.8 unit/L were added to the mixture and incubated for an additional 15 minutes for completing the reduction process of the substrate by the enzyme. The reaction stopped by adding $100 \mu \mathrm{l}$ of $267 \mathrm{mM} \mathrm{Na}_{2} \mathrm{CO}_{3}$ solution. A microplate reader (Versamax ELISA Microplate Reader, USA) was used to measure the absorbance of the solution at $400 \mathrm{~nm}$. Each test was repeated three times. Acarbose was demonstrated as a positive control.

A solution system contains substrate and enzyme, without extract was used as blank and solution system without enzyme was used as a control. The percent inhibition of the enzyme by samples were performed by following formula:

Inhibition $(\%)=[($ blank absorption - sample absorption $) /$ blank absorption] x 100.

The fraction with the highest percent inhibition was further calculated in the $\mathrm{IC}_{50}$ value. The $\mathrm{IC}_{50}$ value showed the concentration of extracts or fractions required to inhibit $50 \%$ of $\alpha$ glucosidase enzyme activity. The $\mathrm{IC}_{50}$ value was calculated using GraphPad Prism 7.0 software.

\section{RESULT AND DISCUSSION}

\section{Assay for Inhibition of Alpha-Glucosidase of G. lateriflora Extract}

The inhibitory activity of methanol, ethyl acetate, and nhexane extracts of Garcinia lateriflora Blume. leaves against yeast $\alpha$-glucosidase enzyme were evaluated. As shown in Table 1 , the methanol extract is the most active extract by exhibit the lowest $\mathrm{IC}_{50}$ value, followed by ethyl acetate and $\mathrm{n}$-hexane extract, which is $31.27 \mu \mathrm{g} / \mathrm{ml}, 34.79 \mu \mathrm{g} / \mathrm{ml}$, and $92.33 \mu \mathrm{g} / \mathrm{ml}$, respectively. 
Table 1: Percent inhibition and $\mathrm{IC}_{50}$ values from extract of Garcinia lateriflora Blume. Leaves.

\begin{tabular}{cccccccc}
\hline \multirow{2}{*}{ Extract } & \multicolumn{7}{c}{ Concentration $(\boldsymbol{\mu g} / \mathbf{m l})$} \\
\cline { 2 - 8 } & $\mathbf{3 . 1 8}$ & $\mathbf{7 . 9 5}$ & $\mathbf{1 5 . 9}$ & $\mathbf{2 3 . 8 5}$ & $\mathbf{3 9 . 7 5}$ & $\mathbf{7 9 . 5}$ & $\mathbf{I C}_{\mathbf{5 0}}$ \\
\hline n-hexane & $0.19 \pm 0.2$ & $0.73 \pm 0.4$ & $2.04 \pm 1.1$ & $4.18 \pm 1.1$ & $15.35 \pm 2.3$ & $41.93 \pm 3.1$ & 92.33 \\
EtOAc & $3.75 \pm 0.1$ & $9.57 \pm 0.5$ & $16.23 \pm 1.0$ & $27.38 \pm 0.6$ & $50.62 \pm 1.0$ & $72.66 \pm 0.7$ & 34.79 \\
MeOH & $0.62 \pm 0.1$ & $4.06 \pm 0.6$ & $17.77 \pm 2.8$ & $32.80 \pm 1.3$ & $63.18 \pm 0.7$ & $87.96 \pm 1.7$ & 31.27 \\
Acarbose & - & - & - & - & - & - & 39.53 \\
\hline
\end{tabular}

Percent inhibition was performed by mean \pm SEM.

Table 2: Percent Inhibition of fractions from Ethyl Acetate Extract.

\begin{tabular}{cc}
\hline Fraction & Percent Inhibition (\%)* \\
\hline EA1 (n-hexane : EtOAc) & $15.65 \pm 1.0$ \\
EA2 (n-hexane : EtOAc) & $11.52 \pm 1.6$ \\
EA3 (n-hexane : EtOAc) & $8.39 \pm 1.9$ \\
EA4 (n-hexane : EtOAc) & $4.00 \pm 2.0$ \\
EA5 (n-hexane : EtOAc) & $11.00 \pm 2.0$ \\
EA6 (n-hexane : EtOAc) & $5.95 \pm 2.6$ \\
EA7 (n-hexane : EtOAc) & $15.91 \pm 0.7$ \\
EA8 (n-hexane : EtOAc) & $27.51 \pm 5.0$ \\
EA9 (n-hexane : EtOAc) & $24.77 \pm 3.0$ \\
EA10 (n-hexane : EtOAc) & $32.51 \pm 1.41$ \\
EA11 (n-hexane : EtOAc) & $25.34 \pm 1.9$ \\
EA12 (n-hexane : EtOAc) & $52.28 \pm 1.7$ \\
EA13 (n-hexane : EtOAc) & $64.23 \pm 0.9$ \\
EA14 (n-hexane : EtOAc) & $26.47 \pm 2.62$ \\
EA15 (EtOAc : MeOH) & $18.69 \pm 2.5$ \\
EA16 (EtOAc : MeOH) & $10.95 \pm 1.4$ \\
EA17 (EtOAc : MeOH) & $23.29 \pm 2.8$ \\
& \\
Acarbose & 39.53 \\
EA13 & \\
\hline
\end{tabular}

*The percent inhibition (\%) was performed in mean \pm SEM at consentration $15.9 \mu \mathrm{g} / \mathrm{ml}$.

Table 3: Percent Inhibition of Fractions from Methanol Extract.

\begin{tabular}{cc} 
Fraction & PercentInhibition $(\%)^{*}$ \\
\hline Me1 (n-hexane : EtOAc) & $8.08 \pm 2.3$ \\
Me2 (n-hexane : EtOAc) & $5.30 \pm 1.4$ \\
Me3 (n-hexane : EtOAc) & $49.49 \pm 1.8$ \\
Me4 (n-hexane : EtOAc) & $26.68 \pm 0.5$ \\
Me5 (n-hexane : EtOAc) & $15.48 \pm 2.3$ \\
Me6 (n-hexane : EtOAc) & $2.78 \pm 0.5$ \\
Me7 (n-hexane : EtOAc) & $12.15 \pm 2.8$ \\
Me8 (n-hexane : EtOAc) & $35.91 \pm 1.4$ \\
Me9 (n-hexane : EtOAc) & $34.89 \pm 1.66$ \\
Me10 (n-hexane : EtOAc) & $58.32 \pm 1.6$ \\
Me11 (n-hexane : EtOAc) & $0.61 \pm 0.04$ \\
Me12 (n-hexane : EtOAc) & $22.61 \pm 1.7$ \\
& $\mathrm{IC}_{50}$ Value $(\mu \mathrm{g} / \mathrm{ml})$ \\
Acarbose & 39.53 \\
Me10 & 18.52 \\
\hline The percent inhibition $(\%)$ was performed in mean + SEM at consentration $15.9 \mu \mathrm{g} / \mathrm{ml}$.
\end{tabular}

\section{Fractionation and Inhibition of Alpha-Glucosidase Assay of Fractions}

Fractionation of ethyl acetate and methanol extracts yielded seventeen and twelve fractions, respectively. Preliminary inhibition of $\alpha$-glucosidase test was done using 17 fractions of ethyl acetate and 12 fractions of methanol extract with the same concentration $(15.9 \mu \mathrm{g} / \mathrm{ml})$. The results can be shown in Table 2 and Table 3. Fraction EA13 from ethyl acetate extract has percent inhibition $64.23 \%$, which is the highest percent inhibition among others. While, fraction Me10 of methanol extract, with percent inhibition $58.32 \%$ have the highest percent inhibition. Therefore, fraction EA13 and Me10 were the most active fraction from each extract. Both most active fraction, EA13, and Me10, was performed to determine $\mathrm{IC}_{50}$ value. Fraction EA13 and Me10 has $\mathrm{IC}_{50}$ values $8.96 \mu \mathrm{g} / \mathrm{ml}$ and $18.52 \mu \mathrm{g} / \mathrm{ml}$ respectively.

\section{Identification of Fraction}

The presence of phenolic compound on fraction EA13 was conducted by $\mathrm{AlCl}_{3}$ spray reagent on a TLC plate with compositions of mobile phase were chloroform: acetone: formic 
acid $=4: 1: 0.2$. It was showing positive reaction by give some spot with a yellowish color and exhibited changing in color at UV lamp $365 \mathrm{~nm}$ after spraying by $\mathrm{AlCl}_{3}$. The result can be shown in Fig. 1.

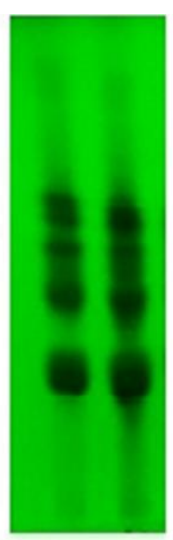

a

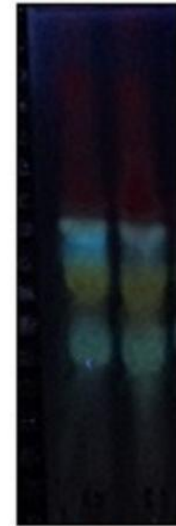

b

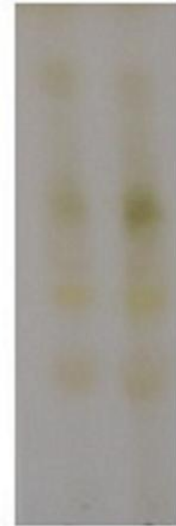

$c$

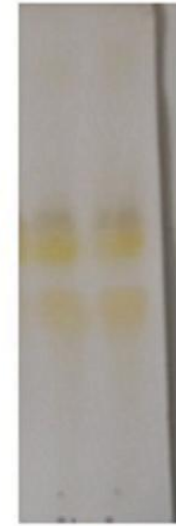

d
Fig 1: The TLC profile of fraction EA13.

(a) UV lamp $254 \mathrm{~nm}$, (b) UV lamp 366 after sprayed by $\mathrm{AlCl}_{3}$ spray reagent $\mathrm{nm}$, (c) Spot visualized by $\mathrm{AlCl}_{3}$ spray reagent, (d) $10 \% \mathrm{H}_{2} \mathrm{SO}_{4}$

\section{DISCUSSION}

The present research is aimed to evaluate the extracts and fractions from Garcinia lateriflora Blume leaves as an alphaglucosidase inhibitor and obtained the most active fraction. Antidiabetic activities were assessed in terms of the ability to inhibit alpha-glucosidase, an intestinal carbohydrate-digesting enzyme. Alpha-glucosidase inhibitors play a significant role as chemotherapeutic agents in the treatment of type 2 DM by delaying carbohydrate absorption and improve postprandial hyperglycemia (Sugihara et al., 2014; Wheni and Tachibana, 2016). However, the present clinical use of alpha-glucosidase in the treatment of type $2 \mathrm{DM}$, such as Acarbose, miglitol, or voglibose, is lack specificity in their action and cause several side effects. So that, the new alpha-glucosidase inhibitor needed to develop (He et al., 2015).

The inhibitory activity of extracts and fractions from the leaves of $G$. lateriflora was investigated against $\alpha$-glucosidase from $S$. cerevisiae with p-NPG as the substrate. The yellow color was produced from the enzyme's degradation product, pnitrophenol, and measured using a microplate reader.

Methanol and ethyl acetate extract from leaves of $G$. lateriflora showed moderate inhibition against alpha-glucosidase. These $\mathrm{IC}_{50}$ values of methanol extract and ethyl acetate extract were lower than of the positive standard, Acarbose. So that, both of the extracts of $G$. lateriflora leaves are more effective than Acarbose. Methanol extract, which has the highest $\mathrm{IC}_{50}$ value, did not show a significant activity at low test concentrations of 3.18 and $7.95 \mu \mathrm{g} / \mathrm{ml}$, but exhibited higher percent inhibition at high test concentration $(15.9 ; 23.85 ; 39.75$; and $79.5 \mu \mathrm{g} / \mathrm{ml})$, compared than ethyl acetate extract. This may be due to the ethyl acetate extract contained compounds which can inhibit the alpha-glucosidase enzyme at low concentrations, whereas compounds in the methanol extract, started working synergistically at higher concentrations. The earlier investigation of phytochemistry contents of $G$. lateriflora extracts reported that ethyl acetate extract contains flavonoids, alkaloids, anthraquinone, glycoside and tannins and methanol extract contains alkaloids, saponin, tannins, glycoside, flavonoids and anthraquinones, while n-hexane extract contained steroids/terpenoids (Elya et al., 2012b). In terms of this condition, so, both of ethyl acetate and methanol extracts were then purified by column chromatography for further investigate the inhibitory activities of alpha-glucosidase. The percent inhibition of each fraction was indicating that not all of the fractions provided good inhibition of $\alpha$-glucosidase. This may depend on the difference in the content of active compounds at each fraction. Fraction EA13, which is the most active fraction, was then identified with $\mathrm{AlCl}_{3}$ spray reagent for preliminary phytochemical screening and reacted positively.

This indicates the existence of phenolic compounds (Yagi et al., 2012). Phenolic compounds, such as phenolic acid, biphenyls, and flavonoid, or proanthocyanidins have been known can reduce a blood glucose level through its mechanism by inhibiting the carbohydrate digestive enzyme, particularly on alpha-glucosidase (Etxeberria et al., 2012). Other research showed that substitution of hydroxyl groups on flavonoid could decrease the inhibitory activity of alpha-glucosidase, therefore increasing the number of free phenolic groups will increase the ability to inhibits alpha-glucosidase (Moradi-Afrapoli et al., 2012). The alpha-glucosidase inhibitory activity has been proven in vitro against yeast $\alpha$-glucosidase or mammalian intestinal $\alpha$-glucosidase enzyme (maltase, sucrose, and isomaltase) and showed high inhibitory activity in many research (Etxeberria et al. 2012; Yao et al. 2012; Yin et al. 2014). In contrast with the promising inhibitory activity of phenolic compound in vitro (Sivasothy et al., 2016), another study showed that no significant inhibition of phenolic compound against rats $\alpha$-glucosidase enzyme in vivo (Zhang et al., 2014).

This research is a preliminary study in order to find active compounds with alpha-glucosidase inhibitory activity. Therefore, further research is needed to isolate the pure lead compound that active biologically as alpha-glucosidase inhibitor from the leaves extract of $G$. lateriflora Blume.

\section{CONCLUSION}

In conclusion, we investigated the inhibitory activities of extracts and the separated fractions which performed by column chromatography from $G$. lateriflora Blume. leaves against yeast $\alpha$ glucosidase. Fraction EA13 of ethyl acetate extract showed promising results in inhibiting $\alpha$-glucosidase with high $\mathrm{IC}_{50}$ value $(8.96 \mu \mathrm{g} / \mathrm{ml})$ under our test condition. Preliminary phytochemical screening with $\mathrm{AlCl}_{3}$ spray reagent showed that the fraction consists of polyphenol compounds. Therefore, we suggest further purification, isolation, and characterization of the lead compound responsible for the inhibitory activity of alpha-glucosidase from the leaves of $G$. lateriflora Blume. 


\section{ACKNOWLEDGMENT}

Financial support and sponsorship: We thank PUPT Grant 2016 by The Ministry of Research, Technology, and Higher Education, Indonesia, for supporting this research.

Conflict of Interests: There are no conflicts of interest.

\section{REFERENCES}

Ahmad I, Arifuddin M, Rijai L. The effect of extraction methods of Bawang Dayak (Eleutherine palmifoliaL. MERR) against TLC profiles and sunscreen activities. Int. J. PharmTech Res, 2016; 9:428-436.

Ahmad I, Yanuar A, Mulia K, Mun'im A. Application of Ionic Liquid based Microwave-Assisted Extraction of the Secondary Metabolite from Peperomia pellucida(L) Kunth. Pharmacogn. J. 2017; 9:227-234.

Derosa G, Maffioli P. $\alpha$-Glucosidase inhibitors and their use in clinical practice. Arch. Med. Sci.2012; 8:899-906.

Elya B, Basah K, Mun'Im, A, Yuliastuti W, Bangun A, Septiana, EK. Screening of $\alpha$-glucosidase inhibitory activity from some plants of Apocynaceae, Clusiaceae, Euphorbiaceae, and Rubiaceae. J. Biomed. Biotechnol, 2012a; 2012:1-6.

Elya B, Katrin, Mun'im A, Hasiholan A, Marlin I, Mailandari M. Antioxidant Activities of Leaves Extracts of Three Species of Garcinia. Int. J. Med. Arom. Plants, 2012b; 2:691-693.

Elya B, Malik A, Septimahanani PI, Loranza B. Antidiabetic Activity Test by Inhibition of $\alpha$-Glucosidaseand Phytochemical Screening from the Most Active Fraction of Buni (Antidesma bunius L.) Stem Barks and Leaves . Int. J. PharmTech Res, 2012c;4:1667-1671.

Etxeberria U, de la Garza AL, Campión, J, Martínez J.A, Milagro FI. Antidiabetic effects of natural plant extracts via inhibition of carbohydrate hydrolysis enzymes with emphasis on pancreatic alpha amylase. Expert Opin. Ther. Targets, 2012; 16:269-297.

He ZX, Zhou ZW, Yang Y, Yang T, Pan SY, Qiu JX, Zhou SF. Overview of clinically approved oral antidiabetic agents for the treatment of type 2 diabetes mellitus. Clin. Exp. Pharmacol. Physiol, 2015; 42:12538.

IDF (International Diabetes Federation). 2015. IDF Diabetes Atlas Seventh Edition. Brussels. Available at: http://www.diabetesatlas.org/resources/2015-atlas.html [Accessed 05 January 2017].

Kosela S, Cao SG, Wu XH, Vittal JJ, Sukri T, Masdianto, Goh $\mathrm{SH}$, Sim KY. Lateriflorone, a cytotoxic spiroxalactone with a novel skeleton, from Garcinia lateriflora B1. Tetrahedron Lett, 1999; 40:157160.

Moradi-Afrapoli F, Asghari B, Saeidnia S, Ajani Y, Mirjani M, Malmir M, Dalatabadi R, Hadjiakhoondi A, Salehi P, Hamburger M, Yassa N. In vitro alpha-glucosidase inhibitory activity of phenolic constituents from aerial parts of Polygonum hyrcanicum. DARU J. Pharm. Sci, 2012; 20:37.

Mun'im A, Katrin, Azizahwati, Andriani A, Mahmudah KF, Mashita M. Screening of $\alpha$-Glucosidase Inhibitory Activity of Some Indonesian Medicinal Plants. Int. J. Med. Arom. Plants, 2013; 3:144-150.
Ngoupayo J, Tabopda TK, Ali MS, Tsamo E. alpha-glucosidase inhibitors from Garcinia brevipedicellata(Clusiaceae). Chem. Pharm. Bull, 2008; 56:1466-1469.

Ren Y, Lantvit DD, De Blanco EJC, Kardono LBS, Riswan S, Chai H, Cottrell CE, Farnsworth NR, Swanson SM, Ding Y, Li XC, Marais JPJ, Ferreira D, Kinghorn AD. Proteasome-inhibitory and cytotoxic constituents of Garcinia lateriflora: Absolute configuration of caged xanthones. Tetrahedron, 2010; 66:5311-5320.

Ryu HW, Cho JK, Curtis-LongM.J, Yuk HJ, Kim, YS, Jung S, Kim YS, Lee BW, Park KH. $\alpha$-Glucosidase inhibition and antihyperglycemic activity of prenylated xanthones from Garcinia mangostana. Phytochemistry, 2011; 72:2148-2154.

Sivasothy Y, Loo KY, Leong KH, Litaudon M, Awang K. A potent alpha-glucosidase inhibitor from Myristica cinnamomea King. Phytochemistry, 2016; 122:265-269.

Sugihara H, Nagao M, Harada T, Nakajima Y, TanimuraInagaki K, Okajima F, Tamura $\mathrm{H}$, Inazawa $\mathrm{T}$, Otonari $\mathrm{T}$, Kawakami M, Oikawa S. Comparison of three $\alpha$-glucosidase inhibitors for glycemic control and bodyweight reduction in Japanese patients with obese type 2 diabetes. J. Diabetes Investig, 2014; 5:206-212.

Wheni A, Tachibana S. Bioactive constituents from the leaves of Quercus phillyraeoides A . Gray for $\alpha$-glucosidase inhibitor activity with concurrent antioxidant activity. Food Sci. Hum. Wellness, 2016; 5:85-94.

World Health Organization. 2016. Global Report on Diabetes. France. Available at: http://www.who.int/diabetes/en/ [Accessed 10 February 2017]

Yagi S, Khristova P, Khalid SA. Chemotaxonomical and Palynological Studies on Nine Acacia Species Occurring in Sudan. J. Plant Stud, 2012; 1:61-67.

Yao Y, Cheng XZ, Wang LX, Wang SH, Ren G. Major phenolic compounds, antioxidant capacity and antidiabetic potential of rice bean (Vigna umbellataL.) in China. Int. J. Mol. Sci, 2012; 13:27072716 .

Yin Z, Zhang W, Feng F, Zhang Y, Kang W. $\alpha$-Glucosidase inhibitors isolated from medicinal plants. Food Sci. Hum. Wellness, 2014; 3: $136-174$.

Zahratunnisa N, Elya B, Noviani A, Zahratunnisa N. Inhibition of Alpha-Glucosidase and Antioxidant Test of Stem Bark Extracts of Garcinia fruticosa Lauterb. Pharmacogn J, 2017; 9:273-275.

Zhang J, Zhao S, Yin P, Yan L, Han J, Shi L, Zhou X, Liu Y, Ma C. $\alpha$-Glucosidase inhibitory activity of polyphenols from the burs of castanea mollissima blume. Molecules, 2014; 19: 8373-8386.

How to cite this article:

Mahayasih PGM, Elya B, Hanafi M. Alpha-Glucosidase Inhibitory Activity of Garcinia lateriflora Blume Leaves. J App Pharm Sci, 2017; 7 (10): 100-104. 